\title{
À MESA COM CÃES E GATOS: RAÇÃO VEGETAL E FRONTEIRAS INTERESPÉCIES
}

\author{
Juliana Abonizio 1 \\ Eveline Baptistella ${ }^{2}$
}

\section{Introdução}

Atualmente, assistimos a inserção crescente de animais na esfera moral, que singularizava a sociedade ou a cultura humanas (Durkheim, 2004; Cardoso de Oliveira, 1994), tanto em razão de descobertas científicas, provenientes, por exemplo, da etologia cognitiva e da neurociência, quanto por meio da emergência de novas sensibilidades que se manifestaram no crescimento de movimentos sociais que atuam na causa animal e nas propostas de leis que visam proteger animais e coibir maus tratos, como a proibição de animais em circo, de criação de animais para extração de pele usada como vestuário, dentre outras iniciativas.

Neste contexto, destacamos o veganismo em sua vertente autointitulada abolicionista. Diferente de outros movimentos, como os protecionistas e bem estaristas que são criticados por não romperem com a dominação especista - os veganos abolicionistas defendem a libertação de todos os animais da subjugação humana e, em termos práticos, recusam-se a consumir produtos que tenham ingredientes animais ou produtos cuja produção tenha causado qualquer tipo de sofrimento animal. Os militantes dessa causa adotam uma dieta livre de produtos cárneos, mas enfrentam um dilema ético ao ter de lidar, quando é o caso, com a alimentação de cães e gatos, consumidores de carne, que, pela situação de domesticação em que se encontram, dependem do ser humano para a sobrevivência.

Diante disso, há um dilema entre as opções de comprar carne para outros animais, em espécie ou em forma de ração, ainda que o próprio sujeito não consuma, ou oferecer uma dieta vegana aos animais que tutela, obrigando-os a uma conduta moral que não faria parte de seu rol natural de escolhas. As soluções para esse dilema podem residir no mercado, de onde vemos emergir marcas rações vegetais para cães e gatos que se aproveitam desse paradoxo para veicular seu produto oferecendo a possibilidade

\footnotetext{
${ }^{1}$ Universidade Federal de Mato Grosso, Brasil.

${ }^{2}$ Universidade Estadual de Mato Grosso, Brasil.
} 
de livrar o dono da culpa pela morte dos animais de criação utilizados na produção das rações comuns.

Para compreender os entrelaçamentos entre as condutas morais e a alimentação de homens e animais, utilizamos o contexto do veganismo abolicionista e outros movimentos com os quais dialoga como pretexto de uma discussão sobre a comensalidade entre humanos e animais de estimação que, em nossa hipótese de início, tornaria difusa a fronteira entre as espécies em questão ao dividirem pressupostos morais referentes ao consumo alimentar. Como material empírico, recorremos à análise da publicidade de marcas de ração vegetal e, valendo-nos de recursos etnográficos de espaços virtuais, coletamos centenas de comentários sobre o tema que foram lidos a partir, principalmente, de referenciais teórico-metodológicos da antropologia da alimentação, estudos de consumo, etologia cognitiva e estudos animais e posteriormente classificados de acordo com o núcleo temático. A partir da procura por termos como cão vegano e ração vegetal em sítios de busca na rede, localizamos postagens e, a partir delas, localizamos outras. As postagens e os comentários foram numerados e fichados, identificamos com o mesmo número os comentários de uma mesma pessoa, a grafia dos textos dos comentários foi modificada em termos de tamanho, fonte, cor a fim de padronizar esteticamente a citação. Também corrigimos eventuais erros de digitação e abreviaturas típicas da linguagem utilizada nas redes sociais, sem, contudo, interferir no conteúdo. Os resultados obtidos apontam para uma remarcação da fronteira que separa e aproxima a animalidade da humanidade ao inserir os animais na dimensão ética que caracteriza, para os humanos, o ato de comer e que transcende em muito a busca por nutrientes. Assim, a alimentação dos animais que era vista como um imperativo de sua natureza herbívora, carnívora ou onívora passa a ser inserida na dimensão cultural que caracteriza a alimentação humana e sujeita, portanto, ao contex to em que se encontra.

\section{Alimentação, biologia e cultura}

Cada indivíduo de cada espécie onívora, à exceção do humano, que contava com o aprendizado cultural, passa sozinho pelo dilema do onívoro discutido por Pollan (2007). Hoje, os humanos retornam a este dilema diante da tamanha oferta de produtos e da ignorância do que efetivamente eles são, o que gera insegurança, segundo o autor. No caso dos animais de estimação, são os tutores que passam pelo dilema dos seus 
animais, impedindo que estes passem sozinhos pela experiência que seria própria da sua espécie.

Se o dilema do onívoro pode ter sido uma das razões do crescimento e complexidade do nosso cérebro, ao impedir que os pets passem por este dilema, os infantilizamos e impedimos o seu próprio desenvolvimento - padrão, aliás, que é um traço marcante da convivência entre humanos e pets. Vale ressaltar que a infantilização, de tudo e todos, é uma característica da subjetividade capitalística discutida por Guattari (Guattari; Rolnik, 2004) manifesta no impedimento de processos de singularização ou de reapropriação da subjetividade.

Para Romanelli (2006), estudar objetos que envolvem a cozinha é importante por trazer a reflexão sobre a relação entre o natural e o cultural, sendo o ato de se alimentar situado entre ambas as dimensões. Disso resulta que muitas das interdições alimentares nada têm a ver com a biologia, mas com aspectos simbólicos que classificam tais e quais alimentos como nocivos.

Para Mary Douglas, as noções de impureza e contaminação só fazem sentido se pensadas em referência a uma estrutura total de pensamento, assim, a autora questiona: "Por que o camelo, a lebre e o hírace seriam impuros? Por que alguns gafanhotos, mas não todos, seriam impuros? Por que seria a rã pura e o camundongo e o hipopótamo impuros?" (1976: 57). As interdições não se encontram na natureza, assim, aquilo que comemos tem mais sentido simbólico que determinações biológicas e mesmo os "bens que servem às necessidades físicas - comida ou bebida - não são menos portadores de significado do que a dança ou a poesia." (Douglas; Isherwood, 2009: 120).

$\mathrm{Na}$ contemporaneidade, assistimos a interdição da carne de quaisquer animais por razões de crenças de saúde, motivações éticas e preocupações ambientais questionando ou negligenciando uma suposta natureza onívora da humanidade ${ }^{3}$ e, dentre esses movimentos, destacamos a vertente vegana abolicionista.

\footnotetext{
${ }^{3}$ Afirmamos que a natureza onívora da humanidade é suposta porque há divergências quanto a esse ponto entre os consumidores de carne e os que optam por não fazê-lo. Os primeiros defendem o onivorismo considerando, por exemplo, a existência de caninos em mandíbulas humanas e os segundos negam o onivorismo ao considerar o tamanho do intestino humano mais apropriado à ingestão exclusiva de vegetais. Essa discussão pode ser vista em Abonizio, 2016.
} 


\section{1 - Veganismo, alimentação, ética e política}

A abstinência total ou parcial do consumo de carne e dos derivados de animais pode ser motivada por crenças religiosas, como a adoção do vegetarianismo em certas vertentes budistas e pelos adventistas do Sétimo Dia (Fraser, 2003, apud Fox; Ward, 2008), na restrição da carne de porco a judeus e islâmicos e da carne bovina na Índia (Beardsworth; Keil, 1992). No entanto, há vegetarianos que tem motivações laicas (Whorton, 1994), como a busca por saúde ou cura, a evitação de exploração e morte de animais por princípios éticos ou a crença que uma alimentação vegetariana seria mais sustentável. As motivações podem ainda ser entrecruzadas, alternando-se em ordem de prioridade através da reflexividade de cada ator. (Abonizio, 2016)

Segundo Beardsworth e Keil (1992), os vegetarianos podem ser classificados em seis categorias não fixas e podem transitar entre elas em ambos os sentidos, do mais rigoroso ao menos rigoroso e vice-versa. Na primeira categoria, situam-se os que se identificam como vegetarianos, mas aceitam ocasionalmente a ingestão de carnes, em geral, brancas, passando pelos piscovegetarianos, lacto-ovo-vegetarianos e outros até o pólo mais rigoroso, os que não consomem nenhum produto de origem animal. Neste último pólo, encontram-se os vegetarianos estritos. A alimentação estritamente vegetal é um dos elementos que compõe a identidade vegana, mas esta não se limita à restrição alimentar.

O veganismo funda-se em princípios éticos em relação aos animais e defende o fim de toda exploração dos animais, agindo na forma de boicote ao consumo de quaisquer produtos que gerem morte ou danos em seu processo de produção, uso ou testes. Assim, os veganos recusam-se a ingerir produtos cárneos e lácteos, além de ovos, mel e gelatina, não utilizam sapatos, roupas e acessórios que contenham seda ou couro, boicotam empresas que utilizam testes em animais, sejam para produtos de saúde, higiene e outros e são contra a utilização de animais para diversão, em zoológicos, circos e rodeios (Abonizio, 2013).

Estes são contornos gerais que compõem o que se entende por veganismo, contudo, a identidade vegana associada a uma causa pode inseri-la na categoria de movimento social e sua atuação pode ocorrer em outras esferas além do boicote a produtos. Aí percebemos algumas subdivisões no movimento, pois há pessoas que se identificam como veganas, tendo uma atuação restrita ao boicote de consumo alimentar 
ou ligado ao vestuário, sendo menos rigorosas em relação aos produtos em geral enquanto outras inserem-se mais diretamente nas causas políticas, libertando animais de cativeiros, intervindo ativamente por mudanças nas leis relativas a causa animal, dentre outras manifestações.

Também assistimos a mudança de terminologias para referir-se aos animais de companhia e à relação que com eles se estabelece, inclusive em fóruns de Direito Ambiental. Por exemplo, notamos a preferência pelo termo tutela em substituição do termo posse que passou a ser preterido nas discussões de vários ativismos ligados à causa animal e tem influenciado políticas públicas e mudanças na esfera do direito. Segundo Santana e Oliveira (2004), é preciso substituir posse responsável para guarda responsável, pois o termo posse sugere que o animal é considerado um objeto e a mudança no termo atuaria positivamente na superação do processo de coisificação da vida, vida, que por definição, não se sujeita à propriedade. Além disso, segundo os autores, a ideia de posse é contrária aos valores de respeito à vida do SISNAMA e da Constituição Federal. Atualmente, vemos iniciativas favoráveis a essa mudança de termo em âmbito municipal, como a Lei Trípoli, de São Paulo, fundada na concepção de guarda responsável e de educação para tal.

A Primeira Reunião Latino-Americana de Especialistas em Posse Responsável de Animais de Companhia e Controle de Populações Caninas, realizada em 2003, produziu uma definição de Guarda Responsável que engloba os deveres dos guardiões acerca das várias necessidades dos animais tutelados (Santana; Oliveira, 2004).

Atualmente, as ideias de tutela e guarda estão mais presentes nos discursos dos movimentos que atuam na causa animal, como constatamos inclusive em um dos textos selecionados para nossa análise, justamente intitulado "Animais carnívoros mantidos sob guarda humana” (Felipe, 2015b). Por tais razões, tanto nas dimensões políticas, jurídicas e pela consideração à linguagem nativa, usaremos o termo tutor e não dono quando falarmos da relação de afeto entre humano e animal de companhia.

Ao longo da história do veganismo no contexto dos vários movimentos ligados à causa animal, de certo modo, bastante recente, foram surgindo questões polêmicas e tentando se elaborar princípios norteadores que servissem como guia para a conduta vegana. Autores diversos - e por vezes com posições contraditórias - discutem os princípios da libertação animal e pessoas envolvidas na causa elaboram termos novos e 
reflexões que consideram pertinentes a um amadurecimento e maior delimitação do que se entende por veganismo enquanto causa.

Dentre as polêmicas e os princípios que dividem os militantes da causa animal está a tutela de animais domésticos e é essa questão que divide os veganos e outros movimentos (e também divide internamente os próprios veganos), que pretendemos abordar, no que se refere a dois pontos específicos: 1- a dieta dos animais tutelados e 2a própria existência de animais tutelados.

Como vimos, os princípios e as práticas veganas situam-se, em grande medida, na esfera do consumo, não apenas alimentar, o que insere essa esfera em um domínio simbólico e político para além das necessidades que satisfaz. Mas e o consumo do bicho, também é simbólico? Quem é de fato o consumidor, quem compra ou quem usa? O que podemos dizer sobre a alimentação dos animais? Esta está restrita às necessidades biológicas ou também pode ter restrições baseadas em princípios morais? Se, de certa feita, já nos separávamos dos animais com a dicotomia entre o cru e o cozido, este último marcando a entrada e permanência do homem no mundo da cultura (Lévi-Strauss, 2004), agora podemos dizer que as fronteiras foram banidas e ambos, humanos e não humanos nos alimentamos de biscoitos artesanais e comidas industrializadas que se remetem a uma ideia de sintonia com a natureza?

\subsubsection{Surgimento da categoria Pet e Comida}

Existem muitos estudos buscando estabelecer o momento e a maneira como humanos e alguns animais desenvolveram laços de afeto. Nas culturas ocidentais, os cães, chamados há gerações de "melhores amigos do homem", parecem figurar em primeiro lugar nesta hierarquia de amizade. Conforme Velden (2009: 139), a história de sua parceria com os humanos é alvo de diversas pesquisas e teorias que formam um conjunto de narrativas marcado pela controvérsia e por diferentes visões. A complexidade das formas de convivência entre animais humanos e não-humanos leva a uma miríade de modelos de relações.

(...) o cachorro domesticado, conquanto um espécie única e singular (...), apresenta características diferentes segundo as modalidades de relação que estabelecem com os seres humanos, dependentes de universos simbólicos e práticas sociais culturalmente específicos de tratar os animais. (Velden, 2009: 140). 
Assim, ainda hoje cães cumprem funções de segurança em diversas capitais brasileiras, inclusive havendo empresas que alugam os animais para tal serviço, servem de alimento em alguns países asiáticos (Campbell, 2016: 1) e em algumas tribos da África e da Nicarágua constituem ferramentas fundamentais para a caça (Hare; Woods, 2012).

Atualmente, a espécie ocupa ainda um novo papel social, além das funções que seus membros já ocupavam e continuam ocupando, ainda que em menor número, sobretudo nos grandes centros urbanos, como guarda e companhia. Referimo-nos a categoria pet que confere contornos específicos à relação entre humanos e cães - e também outros animais -, estabelecendo-as no afeto e no consumo.

O termo pet é utilizado para designar um tipo específico de negócio desde 2012, ano em que o Ministério da Agricultura, Pecuária e Abastecimento criou a Câmara Setorial da Cadeia Produtiva dos Animais de Estimação - ou simplesmente Câmara Pet (Brasil, 2012), voltada para a aquisição de produtos e serviços destinados aos animais não-humanos que se enquadrarem nesta categoria, que é bastante difusa, conforme mostra nota do próprio Ministério:

São animais criados para o convívio com os seres humanos por razões afetivas, gerando uma relação benéfica. Têm como destinações principais: terapia, companhia, lazer, auxílio a portadores de necessidades especiais, esportes, ornamentação, participação em torneio e exposições, conservação, preservação, criação, melhoramento genético e trabalhos especiais. Os principais grupos animais são: aves canoras e ornamentais, domésticas, silvestres e exóticas; cães; gatos; peixes ornamentais e outros (répteis, pequenos roedores, pequenos mamíferos), domésticos, silvestres e exóticos (Brasil, 2012: 1).

Etimologicamente, o termo pet refere-se a animal domado, originalmente em escocês, e em dialetos do norte da Inglaterra, de origem desconhecida. O sentido de criança mimada (indulged child) é de 1500, registrado antes do seu uso para designar animal estimado, que se dá em 1530. O termo é provavelmente associado com o termo "petty", um termo de conotação afetiva, registrado em 1849. (Online Etymology).

Uma análise dos dados da Pesquisa Nacional de Saúde, realizada pelo Instituto Brasileiro de Geografia e Estatística - IBGE, mostra que já existem mais cães que crianças nos lares brasileiros: 
(...) de cada 100 famílias no país, 44 criam cachorros, enquanto só 36 têm crianças. (...) o resultado do cruzamento de dados saiu apenas na semana passada. Ele apontou a existência de 52 milhões de cães, contra 45 milhões de crianças até 14 anos - uma situação que se assemelha à de países como o Japão (16 milhões de crianças, 22 milhões de animais de estimação) e os Estados Unidos (em 48 milhões de lares há cães; em 38 milhões há crianças) (Ritto; Alvarenga, 2015: 71).

Os laços de amor podem ser traduzidos em estatísticas financeiras: o mercado brasileiro de produtos para animais de estimação é o segundo maior do mundo e faturou, em 2014, US\$ 7,2 bilhões (Ritto; Alvarenga, 2015: 74).

A convivência de humanos e pets forma, segundo Faraco (2008), forma um conjunto familiar específico denominado de família multiespécie. Neste tipo de convivência, até $80 \%$ deles são considerados membros da família, 35\% deles dormem na mesma cama que o dono e 30\% protagonizam festas de aniversário (Versignassi, Garattoni, Urbim, 2009). Apesar de ser frequente apelidar cães e gatos de filhos, podemos dizer que essa classificação é metafórica, no entanto, sê-lo não anula a força do símbolo que manifesta a intensidade do afeto que é destinado a esses bichos e o lugar deles é a casa, como Osório diagnosticou em sua pesquisa sobre protetores de gatos recorrendo a discussão sobre a casa e rua feita por DaMatta ${ }^{4}$ :

O imaginário do grupo aponta o animal de estimação como aquele que deve, necessariamente, habitar o ambiente doméstico. Este ambiente, por sua vez, é o da família, o do cuidado, o do amor, o da proteção. A rua é sua antítese. Nesta perspectiva, o animal é tomado como um ser extremamente frágil, que depende de humanos para sobreviver e cujo habitat é essencialmente humano, posto que uma casa humana. Não são criaturas da natureza, por assim dizer, mas da cultura, se tomarmos o universo humano como estritamente cultural. Nesse sentido, ganham uma posição dentro deste universo, não apenas como animais de estimação, o que os diferencia de outros animais, mas como membros de uma família humana, seu habitat necessário. (Osório, 2011, s/p)

Apesar da convivência entre humanos e demais animais ser antiga e permeada por afeto em várias manifestações, temos razões para crer na singularidade da categoria pet como uma característica da cultura contemporânea. Mais que um animal de companhia, o pet é um animal ao qual se tem devoção, não no sentido totêmico, ainda que dele não completamente se dissocie, mas referente, sobretudo, ao tempo e ao dinheiro que lhes são sacrificados. Falando em dinheiro e tempo, dois recursos dos quais sempre se queixam de escassez, chegamos a falar de um mercado destinado aos

\footnotetext{
${ }^{4}$ A autora refere-se à obra MATTA, Roberto da. A casa e a rua: espaço, cidadania, mulher e morte no Brasil. Rio de Janeiro: Rocco, 1997.
} 
tutores - e futuros tutores - de pet, no caso, o mercado voltado à alimentação dos que se encontram sob essa categoria.

Levando em conta questões meramente fisiológicas, Jorge (2014) lembra que os cães fazem parte da ordem mamífera carnívora, mas sua dieta é bastante variada: o consumo exclusivo de carne não é uma regra, pelo contrário, muitos integrantes deste grupo taxonômico comem também frutas e outros tipos de vegetais. Inclusive, não há consenso científico sobre o tipo de alimento que lhes seria mais adequado. Carciofi (2006) afirma que os cães precisam de altos níveis proteicos em suas dietas - mínimo de $18 \%$ para adultos e $22 \%$ para filhotes - no entanto, eles são considerados onívoros por muitos e ainda há debates sobre qual tipo de proteína seria mais adequado a eles: animal ou vegetal.

Conforme Sahd, (2015: 91) tanto a dieta de rações industrializadas quanto uma dieta natural com alimentos caseiros podem trazer efeitos adversos para a saúde dos cães. A primeira pode provocar cálculo renal e contém compostos cancerígenos enquanto a segunda pode levar à obesidade e tem risco aumentado de deterioração e contaminação. Além disso, as necessidades nutricionais de cada raça variam e "as rações secas desenvolvidas por cientistas contam com uma enorme gama de vitaminas sintéticas calculadas com base nos critérios específicos de raça, porte e idade dos peludos" (Sahd, 2015: 92).

Para os tutores, ficaria o peso de escolher qual alternativa considera mais segura para o seu ente querido, levando em conta, talvez, o que lhe faria menos mal, já que todas as opções oferecem riscos. Soma-se a esta questão o fato de homens e cães são biologicamente diferentes:

O próprio Conselho Federal de medicina Veterinária costuma se posicionar contra a prática da alimentação caseira, porque uma alimentação balanceada para cães (carnívoros, com tendências onívoras) não é o mesmo que uma alimentação balanceada para nós (completamente onívoros). (Sahd, 2015: 92).

No entanto, não são apenas as necessidades ou conformações biológicas que entram nesta análise. Voltamos então à questão do gosto como fator da decisão de consumo. O que o animal gosta - e o tutor também - deve ser consumido, mas, deve ser consumido principalmente aquilo que ele necessita. Neste caso, em específico, o gosto é inferior à necessidade como fator de decisão. Mas, em se tratando de consumo humano, o gosto - aquilo que não se discute - é fator preponderante e revelador de autonomia, 
uma vez que, como diz Campbell (2006), ninguém pode mudar o gosto de alguém através de argumentos racionais e o consumo contemporâneo volta-se cada vez menos para a satisfação de necessidades e cada vez mais para satisfação de vontades.

Aos cães e gatos, devem ser dados aquilo que eles gostam, aquilo que eles precisam ou aquilo que não contraria a ética de seus tutores?

É o tutor quem paga as contas e quem decide pelo consumo de seu animal, consumo aqui pensado não no sentido de aquisição mercadológica. Em suma: o cão ou gato - para citar apenas as espécies que mais frequentemente ocupam a categoria pet não decidem o que comem, é o tutor quem o faz e, portanto, é sobre ele que recai a responsabilidade pelo consumo correto ou nocivo daqueles que muitos costumam tratar como filhos de quatro patas.

No estudo feito por Digard (1999), vemos que os animais tem um estatuto familial que, segundo o autor, caracteriza o atual sistema domesticatório. Com esse estatuto, os animais de estimação são submetidos a um tratamento maternal, visto pelo autor como uma forma feminina de adestramento através do afeto que se manifesta em uma hipernutrição desses animais, dentre outros cuidados, que podem inclusive lhes ser nocivos. Para Ingold (2000), a "filhotização" dos animais manifesta essa maternagem referente aos cuidados, cada vez mais ampliados, em termos de recursos e técnicas e mais humanizados.

Não muito diferente do que acontece com crianças que se alimentam mal, a culpa é de quem carrega a carteira e é - ou deveria ser - a autoridade na compra e na decisão de consumo dos menores tutelados. Com cães e gatos a situação se repete: é o tutor o responsável pela alimentação adequada e deve, tanto quanto no caso dos humanos menores estimados, - consultar os especialistas, sejam eles, neste caso, os veterinários ou os fabricantes de ração. Além das rações especiais, vemos crescer a prática de cozinhar para os filhos e filhotes, ambos, crianças e bichos, devem ser alimentados por uma comida mais natural, caseira, sem conserva tendência que se que se manifesta através de "uma indústria de rápido florescimento de livros de receitas para cães e gatos". (Kulik, 2009: 500)

Tal qual se cresce a obesidade humana e a infantil, cresce a obesidade dos pets e para Kulik (2009), a obesidade pode ser interpretada como uma dissolução da fronteira entre espécies. O autor ressalta que os casos de obesidade de animais de estimação tornaram-se um problema social. No entanto, as estatísticas, bastante 
alarmantes, veiculadas pela mídia podem ocultar razões econômicas que aqueceram o mercado dirigido ao pet usando de dois argumentos fundamentais: razões científicas, ainda que duvidosas, e as novas sensibilidades emergentes:

\begin{abstract}
A principal razão pela qual as estatísticas variam tanto é que seu pedigree científico é vago; e a razão para isto é que todas as estatísticas sobre a obesidade de animais de estimação derivam de estudos patrocinados ou conduzidos pela indústria de alimentos para animais de estimação. Ora, essa indústria é uma invenção razoavelmente recente. Ela não existia até o final da segunda metade do século XIX. (Kulik, 2009: 486)
\end{abstract}

Segundo Kulik, James Spratt, ao ver cães revirando lixo em Londres, teve a ideia de produzir biscoitos caninos de carne por volta de 1860 e, dez anos depois, passou a vender os seus produtos nos Estados Unidos. Até então, os animais comiam restos das mesas de seus donos ${ }^{5}$, mas a indústria criou a necessidade do seu produto usando uma publicidade ofensiva que veiculava a qualidade da alimentação especializada.

Atualmente, as marcas de ração apostam nos subsegmentos desse mercado, assim vemos, nas prateleiras de Pet Shops produtos destinados a filhotes e adultos, apropriados para raças de pequeno, médio ou grande porte, castrados, alérgicos, com distúrbios renais e para cães com paladares exigentes - a marca Tutano, por exemplo, oferece uma ração para cães sensíveis, que promete diminuir o risco de alergias. A publicidade, por sua vez, anuncia rações recomendadas por criadores e especialistas, além de escolhidas pelos próprios animais em uma encenação de teste cego.

\begin{abstract}
Um segmento importante da indústria de alimentos para animais de estimação é o chamado Premium ou especial. São as comidas de etapas da vida, que possuem fórmula especial para animais novos ou "seniores", e também as comidas dietéticas. As comidas para etapas da vida ou dietéticas chegam a custar o dobro das normais, mas isto não impede que os donos as comprem, pelo contrário, comida Premium para animais de estimação é o mercado que mais rápido cresce nessa indústria. (Kulik, 2009: 486-487)
\end{abstract}

Ao lado desses produtos específicos, podemos encontrar, agora, a ração vegetal como uma das categorias especializadas.

\footnotetext{
${ }^{5}$ Mantivemos a expressão donos e não tutores, pois esse termo era mais apropriado à concepção de posse de animais no período em questão.
} 


\section{Alimentação vegana para Pets}

Já que a relação afetiva com os animais é mediada pelo consumo, vale refletirmos sobre as dimensões simbólicas que o caracterizam, como mencionamos anteriormente, sobretudo se pensarmos na centralidade do consumo enquanto característica da sociedade contemporânea e foro privilegiado para observa-la e compreende-la.

As ações de consumo podem conferir status, diferenciar camadas sociais e também podem significar pertencimentos ideológicos além ser decisões que interferem na política, na ética e no meio ambiente e expressam posições referentes a cada uma dessas esferas. Em nossa análise específica, debruçamo-nos sobre o consumo alimentar e podemos indagar sobre as motivações e sentidos que as decisões de consumo implicam.

Assim, para alguns, deixar de comer carne é questão ética, para outros é primordialmente ambiental e assim por diante. Cada decisão está fundada numa posição reflexiva e na própria constituição advinda da socialização. Mas e os animais? Podemos atribuir uma questão moral, política e ética em sua decisão de ser vegano ou carnista ${ }^{6}$ ? O dono, ao decidir pelo consumo de seu bicho e manifestar suas posições, legitima o fato de ser ético com um consumo que não é seu?

\subsection{A publicidade da Ração Vegetal}

Diante dos inúmeros produtos dirigidos aos entes queridos denominados pets, estranhamos a publicidade de um produto específico: a ração vegetal destinada a animais que não são herbívoros. No Brasil, a Fridog é a única ração vegetal para cães, sem "ovos, leite, carnes ou vísceras de animais, inclusive peixe e derivados" e é "Enriquecida com Ômega 3 e Ômega 6 (proveniente de fontes vegetais), garante saúde à pele, pelos sedosos e brilhantes." ${ }^{, 7}$ Em sua composição, encontram-se:

Milho integral moído**, farelo de trigo, farelo de soja*, quirera de arroz, Farelo de glúten de milho-60**, Levedura seca de cervejaria, Extrato de leveduras, Óleo de soja degomado* (7\%: ômega 3 0,055\% e ômega 6 3,64\%), Calcário calcítico,

\footnotetext{
${ }^{6}$ Carnismo é um termo utilizado por Joy (2011) para referir-se à ideologia que naturaliza a ideia de matar animais para consumo humano.

${ }^{7}$ As informações referentes à ração Fridog foram extraídas do site www.vegpet.com.br.
} 
Fosfato bicálcico, Cloreto de sódio (sal comum); Cloreto de potássio; Veículo q.s.p, Antioxidante Natural (0,06\% - óleo vegetal, ácido cítrico, dióxido de silício, extrato de tocoferol, essência de alecrim); Extrato de Yucca (0,0625\%), Ácido propiônico; Aluminosilicato de cálcio e sódio; Sorbato de potássio; Aditivo palatabilizante (levedura seca de cana de açúcar, levedura seca de cervejaria, dextrose, ácido fosfórico, sorbato de potássio, tocoferol, óleo de Rosemary); L-Lisina, DLMetionina, Óxido de zinco; Zinco aminoácido Quelato, Sulfato de Cobre; Sulfato de Ferro; Monóxido de Manganês; Iodato de cálcio; Selenito de sódio; Selênio Orgânico; Cloreto de colina; Ácido fólico; Ácido nicotínico; Biotina; Pantotenato de cálcio; Vitamina A; Vitamina B1; Vitamina B12; Vitamina B6; Vitamina D3*; Vitamina E; Vitamina K3; Hexametafosfato de sódio; Mananoligossacarídeo $(0,2 \%)$, Bacillus subtilis $(0,038 \%)$.

* a Vitamina D usada no produto é a D3 proveniente de lã de ovelhas. No momento não existe alternativa no mercado Brasileiro para uma ração $100 \%$ vegana.

Contém soja* e milho** transgênicos

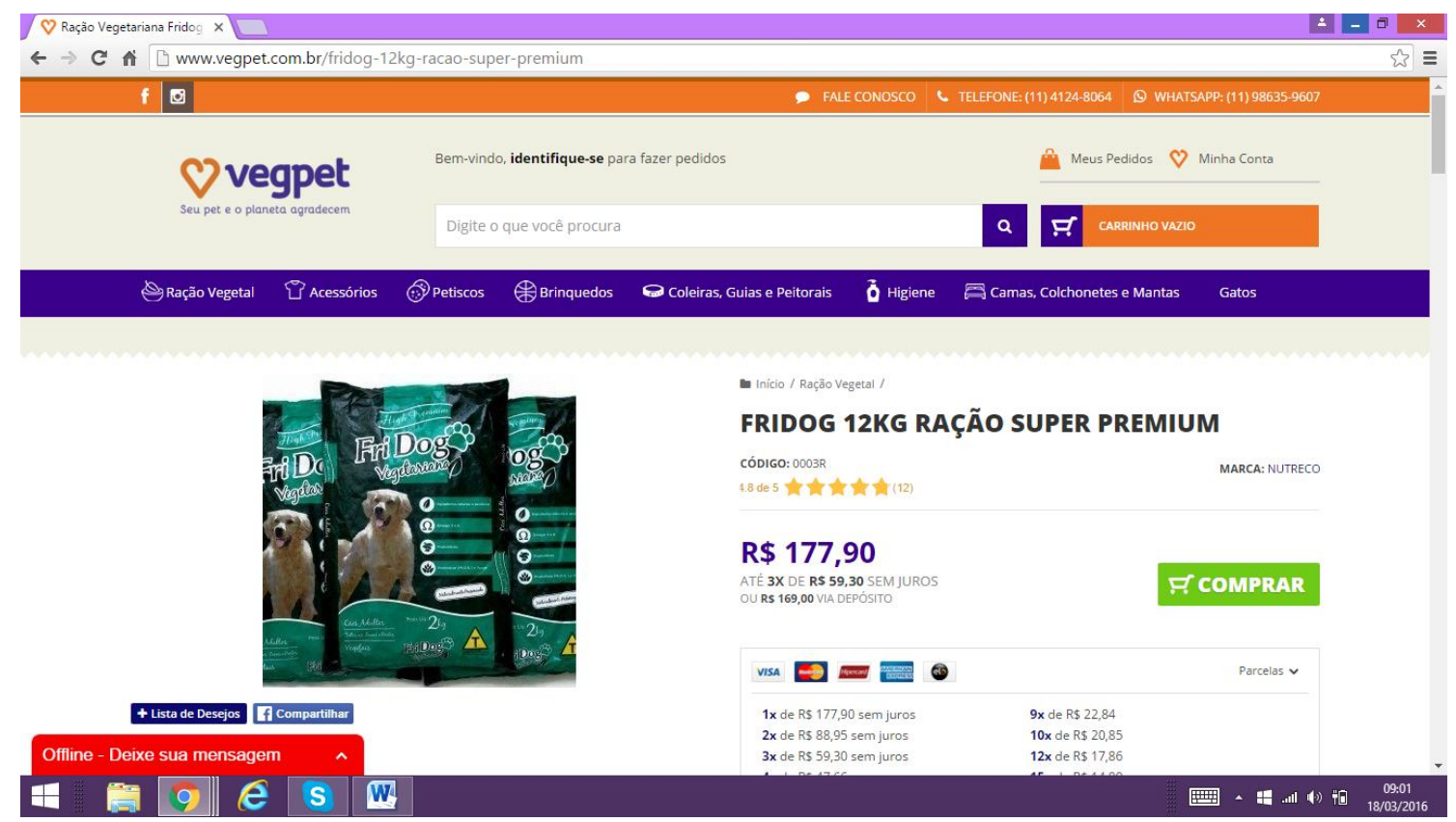

Figura 1: Imagem extraída do site.

Ao analisar os comentários do próprio site, que se afirma como "site sincero"ou seja, que publica todos os comentários e avaliações sem filtra-las - deparamo-nos com perguntas sobre a utilização da lã de ovelha, sobre os motivos da utilização de transgênicos e também - o que mais nos chamou a atenção - questões referentes ao dilema entre a suposta necessidade de alimentos cárneos para a saúde canina e os conflitos morais de compra-los para aqueles que adotam o veganismo. 
Além da ração, a marca produz biscoitos com sabor de banana e maçã ofertados "em uma charmosa embalagem". Os "deliciosos biscoitos $100 \%$ artesanais" são preparados com "ingredientes selecionados e da mais alta qualidade". Os produtos vendidos são relacionados à saúde do corpo e do planeta, apropriando-se do imaginário corrente que associa natureza e saúde, atualizando esta associação na relação entre veganismo e um modo de vida saudável, muito embora, tratem-se de produtos industrializados, ainda que os biscoitos sejam artesanais, segundo a publicidade. Os biscoitos, na foto divulgada, são relacionados a frutas frescas e especiarias, como canela, açúcar mascavo e mel, ainda que açúcar seja impróprio para cães e que mel seja derivado de animais, portanto, não condizente com o veganismo.

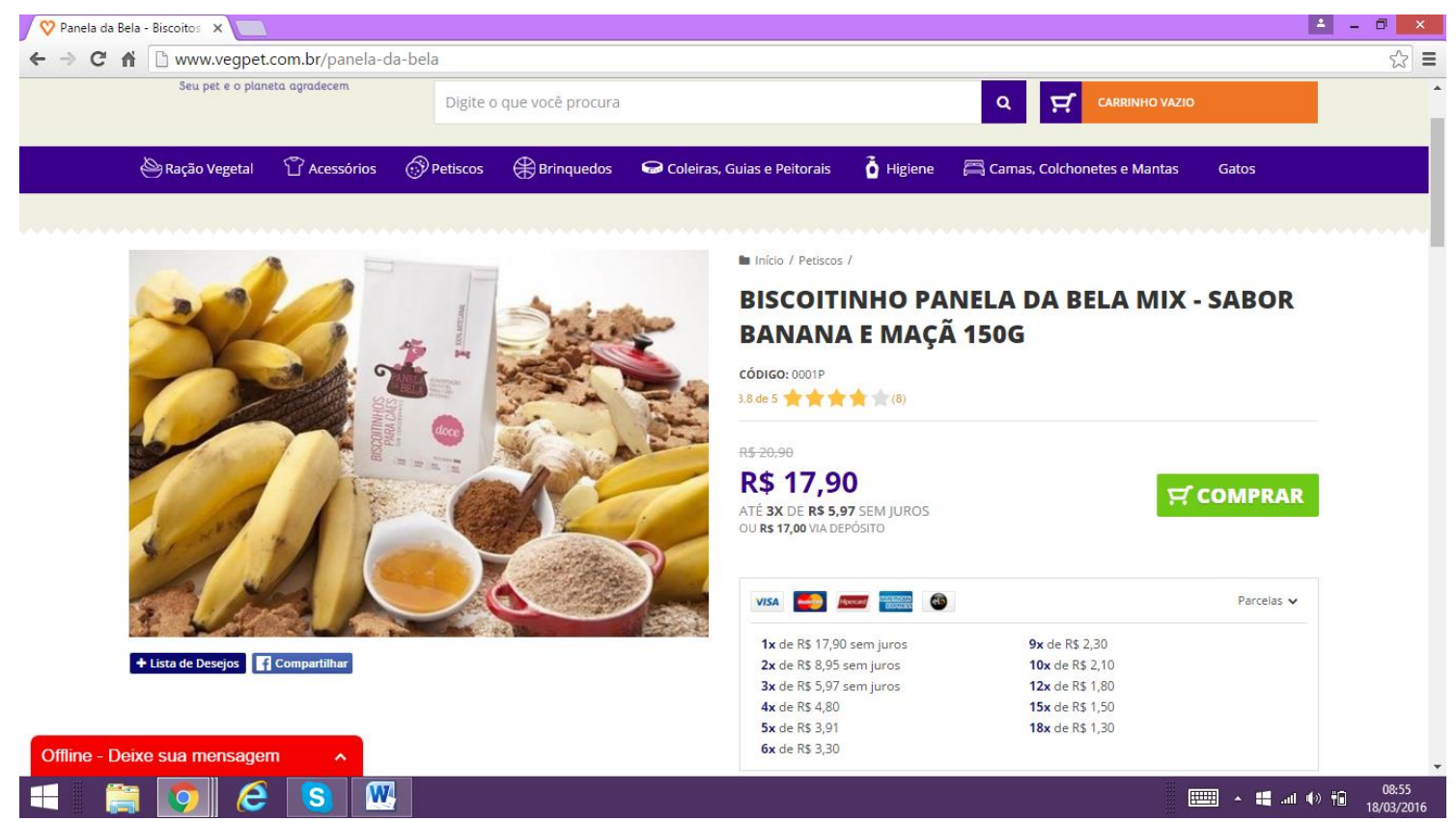

Figura 2: Imagem extraída do site.

Na embalagem, um balão rosa com a palavra "Doce" marca o sabor e alude a uma aproximação entre paladares humanos e caninos. Os tutores usam, por vezes, o seu próprio paladar como referência:

Experimentei e têm mesmo gosto de fruta (bem suave). Meus bichinhos adoraram, mas eles comem até pedras, se estiverem bem temperadinhas. Como por recomendação do homeopata, endocrinologista e clínico geral há anos eles não comem ração, apenas comida natural, essa parece uma sobremesa perfeita! 
No entanto, a palavra final de consumidor é do próprio animal e da manifestação de seu gosto. A maioria dos comentários são variações da frase: Meu cão adorou ou gostou muito!

Diante dessa publicidade, vários estranhamentos nos tomaram: a oferta de alimentos do tipo biscoitos feitos com ingredientes selecionados e expostos de maneira absolutamente igual aos biscoitos dirigidos ao consumo humano, a ideia de uma alimentação saudável e boa para o planeta, a ideia de compartilhar um tabu alimentar coisa até então considerada tipicamente humana - com os pets, a valorização do artesanal e natural, como oposição aos alimentos industrializados, a instituição da sobremesa como parte de uma refeição completa para cães, divisão tipicamente humana, cultural e arbitrária. Enfim, passamos a dividir a mesa com os animais domesticados? $\mathrm{O}$ que essa aproximação na comensalidade expressa nos tipos de alimentos e em suas formas e modos de servir dizem da relação com os animais domesticados na sociedade contemporânea?

O estudo da alimentação do ponto de vista cultural tem abordado os animais não humanos, na maioria das vezes, tão somente quando são transformados em produtos para alimentação humana. No entanto, assistimos a transformação da alimentação dos animais que convivem com humanos a partir de vários elementos sociais, econômicos e culturais que trazem à tona a necessidade de analisar os símbolos e sentidos ocultos na comida ofertada aos pets. Para Amon e Menashe (2008), a comida comunica e é uma forma de contar história. A partir das considerações das autoras, pretendemos nos dedicar a compreender traços da cultura contemporânea através da comida e elegemos a ração vegetal como um caso emblemático dos dilemas postos à mesa.

De um lado, temos os determinantes biológicos que classificam os animais entre herbívoros, onívoros e carnívoros. Em se tratando de animais humanos, apesar da discussão biológica ter alguma importância diante dos debates entre os que adotam uma dieta livre de carne e os que a consomem, vemos que a biologia é, em termos motivacionais para adoção e permanência em determinada dieta, inferior às motivações éticas ou relacionadas às crenças de saudabilidade.

Atualmente, em uma sociedade complexa e fragmentada, há inúmeras possibilidades dietéticas fundadas nas mais diferentes práticas e vertentes teóricas e o consumo alimentar tem se tornado um campo de batalhas que envolve questões morais, políticas, econômicas e ambientais. Dentre as formas de ativismo relacionadas ao 
consumo alimentar, destacamos a prática do veganismo, cada vez mais crescente em número e visibilidade. $\mathrm{O}$ veganismo propõe a ruptura da hierarquia humana sobre os demais animais, mas resta a dúvida: animais podem ser veganos? Podem, eles mesmos, atuar em causa própria? A alimentação dos animais pode enfim prescindir de determinantes biológicos e se fundar sobre causas morais?

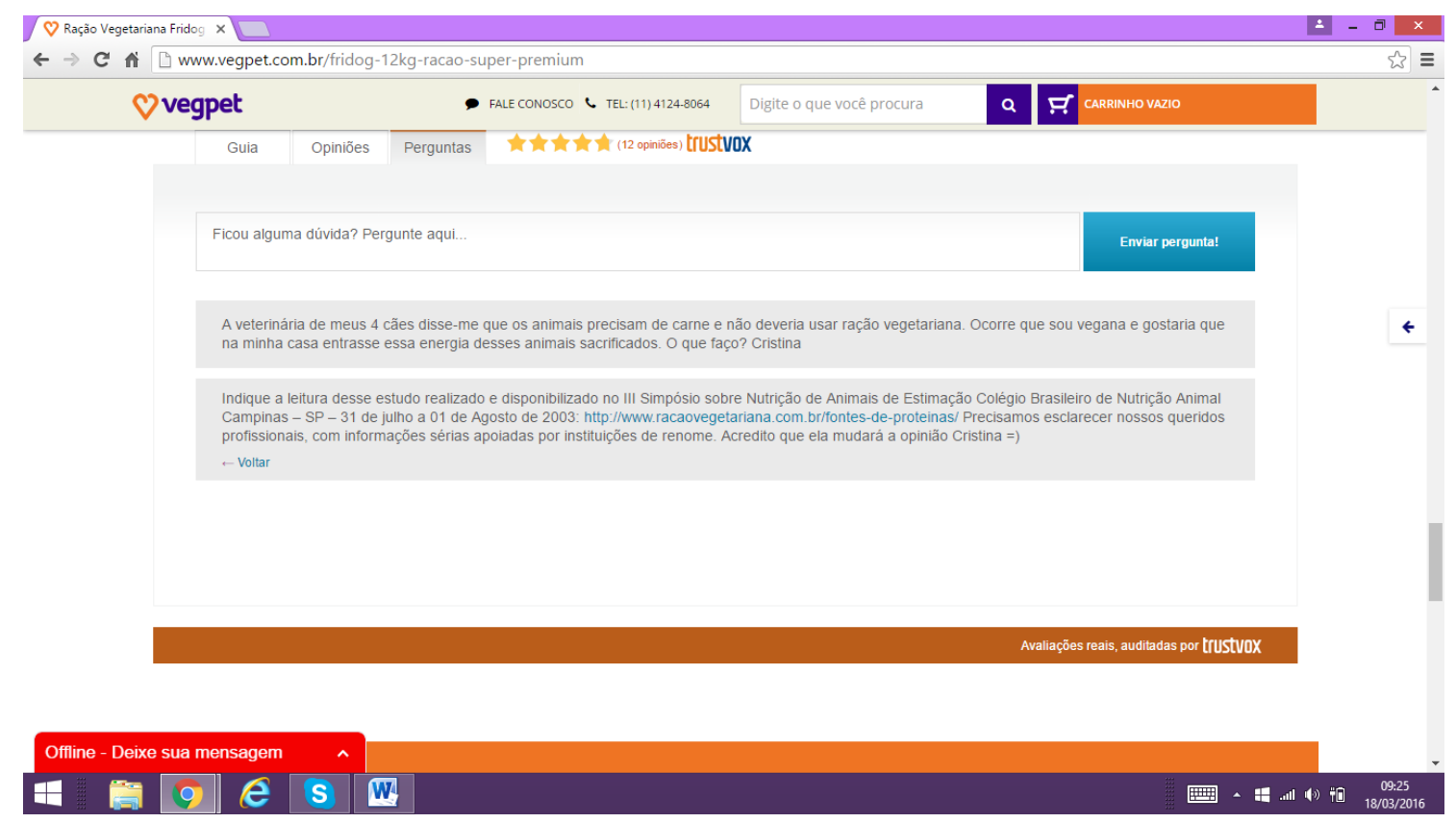

Figura3: Imagem extraída do site.

\subsection{O dilema cotidiano de alimentar os animais tutelados}

Como já abordamos, parte da construção da identidade vegana dá-se na abolição do consumo de carnes e outros derivados de animais, mas e quando o consumo não significa a ingestão ou uso direto, antes destina-se às necessidades biológicas de outros animais, o que fazer? Comprar ou não comprar carne (in natura ou em forma de ração) para seu cachorro ou gato? Comprar produtos cárneos, ainda que não usa-los ou ingeri-los, abala a identidade cuidadosamente construída? Por outro lado, impor uma dieta baseada em valores morais em contrariando a natureza do pet não seria desrespeito e até mesmo uma conduta especista? 
Singer (2010: 110) afirma que o especismo “(...) é o preconceito ou atitude tendenciosa de alguém a favor dos interesses de membros da própria espécie, contra os de outras". Este argumento leva em conta as inúmeras práticas cotidianas que geram dolo aos animais, geralmente, tendo como única finalidade o prazer humano - entre elas alimentação e diversão. No entanto, não seria possível estender este conceito e refletir se a imposição de uma escolha moral humana a um animal de estimação não provocaria, também, uma situação de atitude tendenciosa que contraria o interesse da espécie em questão?

Para entender como as pessoas que adotam o veganismo como guia para suas ações enfrentam esses dilemas em suas vidas cotidianas, recorremos principalmente aos comentários de leitores de quatro textos além, obviamente, dos conteúdos dos próprios textos que foram selecionados a partir de 2 critérios, sendo o primeiro à aderência ao tema do artigo e o segundo pela quantidade de comentários que abordam a alimentação vegetal a pets: 1) É certo estender o veganismo ao seu animal de companhia? (Guimarães, 2013) 2) Direitos das Minhocas (Felipe, 2015a) 3) Animais carnívoros mantidos sob guarda humana (Felipe, 2015b) 4) O preço e o custo da comida pra cachorro (Jacobs, 2013).

O primeiro texto aborda o conflito vivenciado pela própria autora, vegana, em relação a alimentação dos animais com os quais convive e, em um tom de depoimento e desabafo, fala de algumas experiências compartilhadas diante desse dilema.

O segundo e o terceiro são de autoria da professora e militante da causa animal Sônia Felipe, sendo o segundo uma resposta ao questionamento acerca da imposição moral de não matar aos animais. Para a autora vegana, o fato de os animais matarem uns aos outros não implica em uma questão ética que afete os humanos, assim, ela propõe uma separação entre a ética que rege a conduta humana e o comportamento encontrado na natureza; dessa forma, o que os animais fazem uns aos outros, desde que os humanos não tenham sido os responsáveis, é problema deles. Já o texto de número 3 é específico sobre a guarda humana de animais carnívoros e a autora questiona o fato de a sociedade considerar natural matar para comer ou dar de comer. Para ela, se pensarmos na ideia de natureza, veremos que não há nada de natural em terceirizar a morte para alimentar animais tutelados que vivem, ainda segundo a autora, de modo humilhante. Apesar de o primeiro texto não ser específico sobre a alimentação vegetal de animais e de o segundo apenas indiretamente o ser, os comentários se dirigem para a questão da ração vegetal e 
dos dilemas enfrentados, inclusive a autora responde aos comentários que os leitores fizeram em seu próprio texto, o que resulta em um extenso e rico documento.

O último texto, de autoria de Andresa Jacobs, questiona a salvação da vida de um cão com fome através do patrocínio da indústria da morte de animais considerados de corte. Em seu texto, ela faz críticas severas aos abrigos de cães e propõe a adoção do veganismo aos tutores e tutelados, afirmando ainda a necessidade de cozinhar para os animais a fim de aliviar o ônus moral do confinamento de animais considerados de estimação.

Os comentários são bastante numerosos, em especial do primeiro e terceiro texto e alguns contam com respostas também numerosas, revelando que a decisão de consumo alimentar dos animais de estimação gera um conflito intenso, com muitas variáveis e longe de uma posição consensual entre os próprios atores da cena vegana, que, diga-se de passagem, também é variada e conta com subgrupos de diferentes orientações. Para apresentar os dados construídos, classificamos trechos dos textos dos autores da publicação e trechos dos comentários de acordo com os temas levantados e os agrupamos, uma vez há recorrência de posições em todos os casos.

Os temas mais recorrentes foram:

a) Dilema moral de ofertar ou não produtos cárneos para os animais tutelados:

Eu sentia um enorme desconforto moral com a ideia de alimentar um animal carnívoro, como o gato, exclusivamente com vegetais.

Eu aceito e respeito a natureza carnívora do meu gato, mas não quero de maneira alguma usar meu dinheiro para patrocinar a indústria da carne.

Você respeita o direito de viver dos animais que você não come mais, porcos, galinhas, vacas, ovelhas, perus, etc, mas, ao mesmo tempo, mantém sob seu domínio e na sua dependência animais carnívoros e precisa terceirizar a matança de animais para alimentar o seu.

Vivo esse dilema diariamente. Tenho gatos que recolhi das ruas em estados deploráveis e os alimento com ração que tem em sua composição partes de outros animais.

Nunca existirá um mundo vegano sem que os animais que moram conosco tenham uma alimentação vegana estrita.

Esses comentários nos permitem perceber o reconhecimento do dilema vivenciado no cotidiano. Salientamos que a vida contemporânea pode ser considerada dilemática, nos termos de Pais (2010), justamente porque nela se convivem valores 
contraditórios, mas cuja a tensão pode ser fundadora, como aborda Maffesoli (1999). Diante da dificuldade de fazer sentido entre os valores contraditórios: a publicidade implacável da ração como o melhor para o pet (Kulik, 2005), os constrangimentos do sistema perito e da voz dos especialistas (Giddens, 1991) e a ética vegana, o indivíduo constata a existência de um dilema e, em alguns casos, como veremos a seguir, tentam resolve-lo, ainda que o sucesso de tal empreitada esteja longe de consenso.

a) A resolução do dilema baseada na fisiologia animal.

Foi então que li o livreto "Cães veganos: Nutrição com Compaixão", que você pode baixar gratuitamente no site da ANDA. Logo no início o autor diz: "Cães precisam de nutrientes específicos, não de ingredientes específicos" e lembrei que vi um nutricionista falando exatamente a mesma coisa sobre humanos.

Os gatos necessitam de nutrientes específicos, assim como humanos, não de alimentos específicos; portanto há rações veganas adequadas para eles no mercado.

Se o importante para o organismo são os nutrientes, que diferença faz se nessa ração eles são de origem vegetal e nessa outra de origem animal, quando as quantidades estão adequadas pras necessidades dos animais?

Se a cultura contemporânea é bastante fecunda na criação de dilemas, a biologia pode ter uma resposta mais segura, inclusive pelo prestígio de que goza, uma vez que, ao longo do desenvolvimento da ciência e inclusive do desenvolvimento dos ativismos relacionados aos animais, o fato teve sempre precedência sobre o valor (Baptistella; Abonizio, 2016).

Chalmers (1993) argumenta que as bases da confiança na ciência, embora questionáveis, remontam aos primórdios da ciência moderna e se estendem à mídia e ao senso comum. "A ciência deve parte de sua alta estima ao fato de ser vista como a religião moderna, desempenhando um papel similar ao que desempenhou o cristianismo na Europa em Eras Antigas” (Chalmers, 1993: 14). Esta crença parte da premissa de que o saber científico, obtido da observação e coleta de dados seria não apenas mais confiável, mas representaria a verdade. Tal crença, ainda disseminada na contemporaneidade, muito embora seus críticos também sejam bastante atuantes, pode fornecer o conforto de embasar, pela argumentação biológica, a qual se credita a verdade, a exclusão da dimensão cultural alimentar em relação aos animais, pois, estes teriam tão somente necessidades veterinárias e não gozariam da dimensão simbólica da comida, valor considerado intrinsecamente humano. 
a) A amenização do dilema através da obtenção de alimento de formas alternativas.

\begin{abstract}
Uma amiga vegana adotou um filhote de cachorro que encontrou na rua e resolveu o problema da alimentação dele da seguinte maneira. Ela perguntou ao dono de um restaurante/churrascaria aqui da cidade se podia levar pra casa um pouco das sobras de carne (crua) da cozinha. (...) Nenhum animal foi morto especificamente pra alimentar o seu cão/gato, você só estará usando sobras que iriam acabar no lixo. Com duas vantagens suplementares: você estará contribuindo pra reduzir o desperdício de comida nos restaurantes (você ficaria chocado se visse a quantidade de comida que eles jogam no lixo diariamente) e ainda livraria o seu amiguinho das rações industrializadas, que estão longe de ser comida saudável pra eles.
\end{abstract}

Um amigo meu, que é vegetariano, tem um gato, e costuma ir comprar peixe das peixarias da nossa pequena cidade. Ele acha que como é uma exploração pequena de peixe, vinda de barcos de pesca tradicionais, que é melhor do que comprar rações.

(...) mas a questão é bem simples, o restaurante pagou pela carne, (sobras) isso não brotou do nada, então o patrocínio continua, mesmo que indiretamente, não é? As sobras vieram sim, de uma carne que foi comprada, não com o seu dinheiro, mas com o dinheiro de alguém.

Especismo inevitável neste caso (...). Procuro me consolar pensando que a carne que constitui a ração é das sobras da matança destinadas aos humanos...Trata-se de uma compactuação mais fraca com o sofrimento, quase como se eu estivesse a pegar a carne morta do lixo.

(...) a ração de cães e gatos é feita dos restos da indústria da carne; se o mundo virasse vegetariano, com certeza, não matariam um boi para fazer ração, mas desenvolveriam as vitaminas que os gatos precisam sinteticamente, como é com nossa B12. Assim, não me sinto mal em comprar ração pro gatinho, pois não colaborei com a morte da matéria-prima.

Neste bloco de argumentação, vemos que, diante da impossibilidade de se resolver o dilema constatado, o mesmo pode ser amenizado e vivido de forma mais confortável e condizente com os valores que regem as condutas veganas ao procurar obter os alimentos da forma menos danosa possível, seja por carregar valores como sustentabilidade, seja por recusar à compra direta, ou ainda por praticar o boicote às grandes empresas que lucram com a morte e vislumbrar uma espécie de consolo advindo do argumento que mostra a derivação da ração do consumo humano de carne. Obviamente, essas tentativas de solução ocorrem em nível argumentativo, pois a prática continua tendo a conivência com a morte de animais, e, sendo assim, não pode convencer a todos com a mesma eficiência, afinal, o animal foi abatido e a carne comprada "com o dinheiro de alguém". 
a) Defesa e crítica do uso ração vegetal

Que tenhamos a consciência de ADOTAR RAÇÂO VEGETARIANA para nossos animais.

(...) a empresa que a produz [a ração vegetariana] é especializada em produzir alimentos para herbívoros confinados, o que, na minha opinião, a torna ainda pior, já que lucra diretamente com o confinamento de animais.

Se queremos de fato acabar com a domesticação dos animais, seria correto pleitearmos que tragam este tipo de alimento para o Brasil?

Os cães são onívoros, logo é muito fácil adaptarem-se a uma alimentação vegetariana ou mesmo vegana. Os gatos são carnívoros, mas na natureza não caçariam vacas nem porcos nem atuns... Portanto, desde que a ração vegetariana/vegana seja nutricionalmente adequada é segura para os animais de companhia. As rações de carne também têm taurina, arginina, minerais e vitaminas adicionadas de modo a conseguirem esse equilíbrio nutricional, portanto não são mais naturais do que as vegetarianas.

Agora hipotetizemos que todos nos tornemos vegetarianos... e não existam mais "sobras". Como será? É fácil "não fazer parte" da parcela consumidora de carne, mas ao mesmo tempo justificar seus atos de consumo indireto (de manter animais de estimação que precisam dela) em função de uma parcela consumidora dos tais restaurantes. A meu ver, dá no mesmo.

O mercado sinalizou uma solução ao dilema de comprar ou não produtos cárneos ao criar uma ração vegetal. Poderia ser esta uma solução perfeita, já que em termos nutricionais parece adequada e as rações vegetais são tão artificias e industrializadas quanto às feitas com elementos cárneos. No entanto, se o veganismo tem um direcionamento ético em relação ao boicote às empresas que lucram com o sofrimento de animais ${ }^{8}$, como compactuar com uma empresa que produz ração para animais em confinamento?

O terceiro comentário citado no bloco aponta para a discussão que se segue e radicaliza, pois já não se trata do dilema de alimentar, mas trata-se da própria domesticação de animais e a legitimidade disso.

b) Dilema sobre a legitimidade ou não de tutelar pets

Também vale falar que os Humanos são seres culturais e morais, os animais (nãohumanos) não, ter animais de "estimação" dentro de um apartamento, por exemplo, pode ser considerado um ato de crueldade, pois desrespeita a maioria dos requisitos do bem estar dos animais, como o de EXPRESSAR SEU COMPORTAMENTO NATURAL.

\footnotetext{
${ }^{8}$ Veganos podem se configurar como um nicho de mercado de empresas carnistas, porém, uma parte do movimento vegano recusa-se a consumir, por exemplo, alimentos veganos produzidos por empresas que lucram com a morte. Podem negar-se, por exemplo, a consumir pratos feitos com proteína de soja produzidos pela linha Vita Soja da Sadia. Esse debate apareceu em alguns comentários, mas não os destacamos, uma vez que fogem do tema recortado.
} 
No caso destes animais, nós somos os responsáveis pelo fato de eles dependerem agora de nós para obterem um prato de comida. Na natureza, nenhum animal vive deste modo humilhante.

Dizer que é menos pior passar pomada contra sarna no cão, do que deixar que ele fique sofrendo com as sarnas, não é abolicionista, obviamente, porque o ato de passar pomada no cão não o liberta do sistema de detenção ao qual está condenado, porque os humanos gostam de eleger a espécie canina como objeto de estimação.

Se os gatos não estivessem presos nos apartamentos, eles obteriam os aminoácidos essenciais que não encontram nos vegetais por conta própria, seguindo seu metabolismo natural, ainda não evoluído para a dieta vegetariana estrita. Ao deter felinos em nosso meio, criamos o dilema moral de matar ou não para os alimentar. E, então, pagamos para matar.

[Cozinhar para os cães] é um trabalho necessário, se queremos aliviar um pouco o ônus moral dessa loucura que é confinar cães em quintais, pois os muros dos abrigos não são de vidro.

$\mathrm{Eu}$ estou enfrentando alguns problemas em criar animais porque simplesmente os adoro, Além do gatinho, tenho um esquilo da mongólia que tirei de uma gaiola totalmente suja e superpopulada e meu peixinho betta splendens que estava numa garrafa pet cortada ao meio! Os veganos dizem que é maldade criar animais, mas eu não posso criar nem eles?

Se veganos são contrários ao confinamento de animais de produção, sejam galinhas poedeiras, vacas leiteiras ou animais destinados ao abate, porque seriam favoráveis ao confinamento de animais destinados ao afeto? A argumentação do próprio afeto parece frágil em relação à acusação de especismo daqueles que, mesmo em nome do afeto, negam os impulsos naturais e as necessidades dos animais que tutelam, lembrando ainda que, da mesma forma de argumentos apresentados em blocos anteriores, a ideia de natureza tem peso de fato, por ser objetiva e passível de comprovação científica, enquanto que a noção de afeto é um valor que pode, e frequentemente é, inferiorizado em sua retórica.

c) Solucionar o dilema ao tutelar apenas animais herbívoros ou criar um novo dilema

Hoje oriento pessoas veggies a terem animais que correspondam a isso ética e moralmente (...). Cães sem dúvida podem se adaptar a dietas veganas, gatos não.

Incentivar vegano a 'ter' animais herbívoros de estimação vai fomentar uma fatia de mercado pet ainda pequena no Brasil.

Se se aceita a legitimidade da tutela, pode-se livrar do dilema de ter que comprar produtos cárneos ao adotar animais herbívoros, mas, novo dilema se cria, uma vez que o mercado pet, em expansão exponencial, não explora apenas cães, gatos e hamsters. Segundo uma matéria jornalística sobre o interesse pelos animais exóticos que 
passam a ocupar o lugar de pet, nota-se um crescimento ao longo dos anos. Segundo o gerente de uma loja de pets exóticos localizada em Itu, São Paulo, José Carlos de Oliveira Filho, entrevistado para a matéria, registrou-se "um aumento de 30\% mais ou menos a procura por animais silvestres, que a pessoa busca ter com autorização do Ibama”. (Do Gato, 2014).

A prática de comercialização de animais, ainda que seja com finalidade de afeição, é considerada indigna pelo movimento vegano, uma vez que os animais continuam em situação de reificação e exploração, além do que suspeita-se que os processos de criação e venda não são isentos de dor, sofrimento e morte.

d) Aguardar a extinção dos pets com o crescimento do veganismo

Se respeitamos o natural, não manteremos sob nosso domínio animais que precisam comer carnes, porque não há, na natureza, animal algum que pague para matarem o que ele precisa comer. Nós terceirizamos tudo, inclusive a habilidade dos nossos chamados animais de estimação, de obter a seu próprio modo o alimento que atende às suas necessidades.

Então o ideal seria não ter nenhum animal doméstico, somente selvagens e, estes, em seu habitat, sem a interferência humana... ok. E o que faremos com os bilhões de animais domésticos e domesticados que não se adaptam a nenhum local selvagem?

Nenhum animal merece viver fechado em um apartamento. É apenas menos pior que viver na rua. Os cães e gatos devem existir em sua forma selvagem, os domésticos tem que ser extintos.

Não sou contra animal de estimação para mim é um filho! Se isso não é ser vegan então não sou! Porque dou muito amor e cainho a eles.

Em uma sociedade vegana futura, estes animais não seriam reproduzidos conscientemente, e, consequentemente seus números iriam diminuir gradativamente, até chegarem à extinção dessas espécies.

Os argumentos em defesa da ração vegetal são bastante parecidos com os argumentos favoráveis à adesão do veganismo e baseiam-se na saudabilidade, sustentabilidade e ética. Os comentários apresentam divergências, mesmo entre os que compactuam com os princípios norteadores mais gerais do veganismo. De um lado, lastima-se que os animais em situação de rua morram e, de outro lado, se são salvos por humanos, perdem, contudo sua autonomia.

Os comentários dos quatro textos selecionados direcionam o debate acerca da legitimidade e viabilidade de ter ou tutelar animais domésticos e as rações feitas à base de carne, porque, neste caso, haveria a interferência humana direta, por meio da compra e da produção, inclusive pela domesticação dos animais de modo a torna-los 
dependentes para se alimentar. Este conflito parece repousar em uma questão mais ampla, ética, mas também ecológica, que trata do impacto que a criação de animais para o consumo humano tem sobre as condições de vida no Planeta. Além da grande quantidade de sofrimento impingida às espécies que serão consumidas, existe também a questão da degradação ambiental que vem aliada a este modelo de produção.

Nos Estados Unidos, a pecuária consome sete vezes mais grãos do que toda a população humana do país, e os grãos fornecidos ao gado poderiam alimentar 840 milhões de humanos que tivessem uma dieta baseada em plantas. O estudo dos Pimentel afirma que um quilograma de proteína animal requer cerca de 100 vezes mais água do que 1 kq de proteína de grãos. (...) A Organização das Nações Unidas para Agricultura e Alimentação (FAO) afirma que a criação animal contribui com mais gás de efeito estufa na atmosfera, que está ligado ao aquecimento global, do que a queima de combustíveis fósseis para transporte (...) (Francione, 2014: 308).

Financiar a indústria da carne, então, é custear, além do sofrimento animal, a destruição da natureza como um todo. Como possibilidade de amenizar a culpa, os tutores de animais elencam diversas opções, cada uma com pontos positivos e também inconvenientes.

Assim, eles podem escolher conviver exclusivamente com animais herbívoros, correndo o risco de aquecer um mercado que certamente coisifica os animais que são criados em situação de ética duvidosa; recorrer à alimentação vegetal para seus animais, através da oferta de comida, que pode deixar a desejar em termos de praticidade no diaa-dia e provocar carências nutricionais ou através de ração, que pode ter custos elevados e o inconveniente de patrocinar marcas que produzem rações para animais em cativeiro. Uma das opções para superar a contradição entre ser vegano e comprar produtos animais para outros animais (que, não deveriam ser - em tese - dispostos em uma escala hierarquizada) é pegar as sobras dos humanos, o que parece pouco convincente, pois se a luta do movimento é para a universalização do veganismo (e não apenas adotar um estilo de vida que não lhe dê dor na alma), o que fazer com os gatos quando não houver mais produção industrial de carne?

A solução mais radical seria não tutelar os animais e se tornar indiferente aos muitos abandonados que sofrem em situação de rua ao mesmo tempo em que deseja sua extinção com o aumento da conscientização no sentido vegano-abolicionista. Neste caso específico, vemos que não se trata de abolir somente a exploração aos animais, mas abolir qualquer relação com eles, uma vez que, deduzimos, acredita-se na impossibilidade de uma relação que não seja hierarquizada em benefício humano. 
Assim, o fim do sofrimento dos animais de pecuária quando (e se) houver uma mudança total de padrões alimentares no Planeta, levaria, obrigatoriamente, à extinção dos pets carnívoros. Mas, ainda assim, o carnivorismo não seria extinto, pois inúmeros animais selvagens continuariam matando para se alimentar. Esta prática, no entanto, seria aceita, pois a esfera da natureza estaria excluída desta questão moral. A moral que incomoda é relativa aos pets e essa constatação nos mostra mais uma vez a inserção dos pets na família humana, pois estes acabam sendo incluídos no dilema ético dos seus donos.

É válido notar que um dos campos mais explorados dos estudos animais hoje trata justamente da vida emocional dos animais e algumas das pesquisas mais significativas encontram indícios de senso moral nos bichos. Bekoff (2010), por exemplo, revelou a ética existente entre animais a partir do estudo das brincadeiras entre cães. King (2014) recolheu evidências de luto entre os bichos. De Waal (2011) ${ }^{9}$ demonstrou a reciprocidade e empatia nos animais não-humanos, características apontadas por ele como pilares da moralidade. Cultura, linguagem, consciência, personalidade, moral, senso de justiça, entre outras coisas, já não são características exclusivas dos humanos. Neste ponto, entretanto, é preciso pensar no que estas pesquisas podem revelar sobre nosso próprio antropocentrismo, pois ter qualidades intelectuais e morais similares às humanas não significa - ou deveria significar necessariamente que os animais tornam-se merecedores de um status mais elevado.

O embate nos coloca diante da questão do próprio interesse dos animais. Seriam todos os cães e gatos infelizes em seus confinamentos? Eles abririam mão do direito de existir ou aceitariam tranquilamente e sem sofrimento um processo de volta à natureza, ou ao estado selvagem, conforme pleiteiam alguns?

\footnotetext{
9 Palestra "Franz de Wall: moral behavior in animals", proferida por Franz de Waal, no evento TEDxPeachtree, em novembro de 2011.
} 


\section{Considerações finais}

Através dos dados construídos, podemos ver que a convivência entre humanos e animais em contextos urbanos e multiplamente orientada é complexa e poderia levar a várias conclusões. Nos comentários analisados, discute-se sobre a imposição de dietas e a legitimidade de fazê-lo, mas nos conduzem ao diagnóstico de que qualquer dieta é imposta aos animais de estimação, seja ela vegana, industrializada ou cozinhada.

A ideia de como alimentar coerentemente com suas ideologias e eficazmente de acordo com o organismo dos animais domesticados tem gerado intenso debate. A aproximação afetiva entre homens e alguns animais tem promovido a inclusão destes nos espaços domésticos e a adoção de cuidados cada vez mais caros e especializados para eles. Esta aproximação é reforçada pelas constatações de que os animais tem consciência a, pela exigência de direitos e pela alimentação, basicamente industrializada ou de alguma forma humanizada, sejam restos de comida, vegetais e grãos cozidos ou rações feitas por especialistas. Não só pela perspectiva da alimentação o que se vê é um esforço humano em adaptar seu bicho estimado àquilo que julga mais correto ou até mesmo mais cômodo. Assim, os pets tem seu direito reprodutivo negado, seu espaço limitado ao âmbito das residências ou então controlado por telas e coleiras e, por fim, sua alimentação também é determinada por terceiros, passando muito longe daquilo que comeriam se vivessem em liberdade - um extremo que se encontra na adoção da dieta vegetariana para cães e gatos, já que todo aquele que convive com um destes espécimes sabe que é com muita intensidade que manifestam seu interesse por um pedaço de carne.

No caso das rações, defende-se que tenham aquilo que é necessário ao corpo e, com isso, estabelecem uma diferença entre o necessário e o supérfluo, ou entre o necessário e o fruto do desejo. O primeiro, algo veterinário, o segundo, remetendo-se às questões do espírito. Ao ofertar aos animais tão somente suas necessidades básicas - ou seja, básicas exclusivamente ao seu corpo, à sua manutenção biológica - eles são destituídos de qualquer valor que transcenda a essa corpo, como alma, mente ou espírito $^{10}$. A diferenciação entre humanos e demais animais retorna e novamente se instala, pois já é há muito sabido que a comida transcende, para os humanos, os valores nutricionais.

\footnotetext{
${ }^{10}$ A discussão e a crítica sobre a distinção entre bens necessários e bens supérfluos pode ser vista em Douglas e Isherwood, 2009.
} 
Mas, sendo a alimentação uma questão moral, impô-la aos animais, parece imoral, pois lhes retira a autonomia e a moralidade reside na possibilidade de escolhas livre, possibilidade esta que não existe nos animais tutelados.

O movimento que pensa as causas animais mostra-se dividido. De um lado, protetores que salvam vidas de carne e osso e tentam a duras penas manter vivos e sãos os animais considerados pets, ainda que a custo da vida de outros animais. Para aliviar a culpa, pedem-se restos de animais, compra-se ração - já que é feita de expurgo -, ou dão-lhe vegetais. Para os abolicionistas, cientes da ineficiência dessas práticas e da incoerência dessas atitudes, contrários a perda de autonomia dos animais, contrários à manipulação humana de sua alimentação e, já que acham impossível relacionar-se de modo não repressivo com animais, para evitar sua exploração, tornam-se contrários a sua existência.

Os discursos analisados mostram que há sempre um elemento que não é ouvido: o próprio animal. As barreiras de linguagem podem ser utilizadas para argumentar que não é possível saber ao certo o que eles querem. Reforçando o antropocentrismo subjacentes nestes discursos, diferentes grupos buscam dizer o que é melhor para os animais, sem levar em conta os próprios interesses dos bichos. Será que nossos cães e gatos querem ser extintos? Será que a convivência inter-espécies, feita de doses alternadas de afeto e limitações, é tão diferente assim de um relacionamento entre humanos?

\section{Referências}

ABONIZIO, J. Conflitos à mesa: vegetarianos, consumo e identidade. RBCS Vol. $31 \mathrm{n}^{\circ} 90$ fevereiro/2016.

ABONIZIO, J. Consumo alimentar e anticonsumismo: veganos e freeganos. Ciências Sociais Unisinos, v. 49, n. 2, 2013.

AMON, D. \& MENASCHE, R. "Comida como narrativa da memória social". Sociedade e Cultura, 11 (1): 13-21, jan./jun., 2008.

BABTISTELLA, E.; ABONIZIO, J. Entre espécies e ciências: uma reflexão sobre a utilização de argumentos científicos para legitimação da causa animal. INTHERtesis, Florianópolis, v 13 n2 p.76-105, mai-ago, 2016.

BEARDSWORTH, A. \& KEIL, T. "The vegetarian option: varieties, conversion, motives and careers". The Sociological Review, 40 (2): 253-293, 1992.

BEKOFF, M. A vida emocional dos animais: alegria, tristeza e empatia nos animais: um estudo científico capaz de transformar a maneira como os vemos e tratamos. São Paulo: Cultrix, 2010.

BRASIL. Ministério da Agricultura, Pecuária e Abastecimento. Ministério anuncia a criação de cadeia produtiva pet. Brasília, DF, 2012.

CAMPBELL, C. "Eu compro, logo sei que existo: as bases metafísicas do consumo moderno", in L. Barbosa e C. Campbell (orgs.), Cultura, consumo e identidade. Rio de Janeiro, Editora da FGV, 2006. 
CAMPBELL, Joseph. Festival de carne de cachorro na China começa sob protestos. $O$ Globo On-line. Disponível em http://oglobo.globo.com/sociedade/sustentabilidade/festival-de-carnede-cachorro-na-china-comeca-sob-protestos-19549758\#ixzz4NmUnvM9b. Acesso em 19 out. 2016.

CARCIOFI, Aulus; PONTIERI, Roberto; FERREIRA, Cristiana; PRADA, Flávio. Avaliação de dietas com diferentes fontes protéicas para cães adultos. R. Bras. Zootec., v.35, n.3, p.754760, 2006

CARDOSO DE OLIVEIRA, Roberto \& CARDOSO DE OLIVEIRA, Luís R.. Ensaios antropológicos sobre moral e ética. Rio de Janeiro: Tempo Brasileiro, 1996.

CHALMERS, Alan. O que é ciência afinal? São Paulo: Editora Brasiliense, 1991.

DIGARD, Jean-Pierre. Les Français et leurs animaux. Paris, Fayard, 1999.

DO GATO às baratas: animais exóticos ganham espaço. 2014. Disponível em: http://g1.globo.com/sp/bauru-marilia/mundo-pet/2014/noticia/2014/12/mundo-pet-do-gato-

baratas-animais-exoticos-ganham-espaco.html . Acesso em 15/10/2016.

DOUGLAS, M. Pureza e perigo. São Paulo, Perspectiva, 1976.

DOUGLAS, M. \& ISHERWOOD, B. O mundo dos bens: para uma antropologia do consumo. Rio de Janeiro, Editora da UFRJ, 2009.

DURKHEIM, Émile. Da divisão do trabalho social. $2^{\mathrm{a}}$ ed. São Paulo: Martins Fontes, 2004.

FARACO, C. B. Interação humano-cão: o social constituído pela relação interespécie, Porto Alegre, 2008. 107p. Tese (Doutorado) - Faculdade de Psicologia, Pontifícia Universidade Católica do Rio Grande do Sul.

FELIPE, S. T. Direitos das minhocas. Disponível em: http://www.veggietal.com.br/direitosminhocas/. Acesso em 12/03/2016. 2015a.

FELIPE, S. T. Animais carnívoros mantidos sob guarda humana. Disponível em: http://www.veggietal.com.br/carnivoros-guarda-humana/. Acesso em 13/03/2016. 2015b.

FRANCIONE, Gary. Coma com consciência: uma análise sobre a moralidade do consumo de animais. São Paulo: Exempla Press, 2015.

FOX, N. \& WARD, K. "Healt: etics and environment: a qualitative study of vegetarian motivations". Appetite, 50: 422-429, 2008.

GUATTARI, F.; ROLNIK, S. Micropolítica: cartografias do desejo. 2004.

GUIDDENS, A. As Consequências da Modernidade. São Paulo: EDUSP, 1991

GUIMARÃES, S. É certo estender o veganismo ao seu animal de companhia?. Disponível em http://www.papacapimveg.com/2013/02/06/e-certo-estender-o-veganismo-ao-seu-animal-de-

companhia/. Acesso em 25/01/2016. 2013.

HARE, Brian; WOODS, Vanessa. Seu cachorro é um gênio: como os cães são mais inteligentes do que se pensa. Rio de Janeiro: Jorge Zahar Editor, 2012.

INGOLD, Tim. The Perception of the environment: essays on livelihood, dwelling and skill. Londres: Routledge, 2000.

JACOBS, A. O preço e o custo da comida pra cachorro. Coluna Valor à vida. Disponível em: http://www.anda.jor.br/10/03/2013/o-preco-e-o-custo-da-comida-pra-cachorro. Acesso em 24/01/2016. 2013.

JORGE, Rodrigo da Silva Pinto. Caracterização do estado sanitário dos carnívoros selvagens da RPPN SESC Pantanal e de animais domésticos da região. 2008. 105 f. Tese (Doutorado) Curso de Epidemiologia Experimental e Aplicada às Zoonoses, Departamento de Medicina Veterinária Preventiva e Saúde Animal, Universidade de São Paulo, São Paulo, 2008. Disponível em: <file:///C:/Users/Evel/Desktop/Rodrigo_Silva_Pinto_Jorge_atual.pdf>. Acesso em: 25 mar. 2016.

JOY, Melanie. "From Carnivore to Carnist: Liberating the Language of Meat", Satya, 18(2), September, pp. 126-127, 2001.

KING, Barbara. O que sentem os animais? Rio de Janeiro: Odisseia, 2014.

KULIK, Don. Animais Gordos e a dissolução da fronteira entre as espécies. MANA 15(2): 481508, 2009.

LÉVI-STRAUSS, Claude. Mitológicas I - O cru e o cozido, tr. Beatriz PerroneMoisés, R.J.: Cosac e Naify, 2004. 
MAFFESOLI, M. No fundo das aparências. Petrópolis: Vozes, 1999.

ONLINE ETYMOLOGY dictionary. Disponível em: http://www.etymonline.com/index.php?term=pet. Acesso em 27/04/2016.

OSÓRIO, Andrea. Humanidade e não-humanidade: notas sobre um grupo de protetores de gatos de rua. In: $4^{\circ}$ SEMINÁRIO DE PESQUISA DO INSTITUTO DE CIÊNCIAS DA SOCIEDADE E DESENVOLVIMENTO REGIONAL. Universidade Federal Fluminense - UFF. Campos dos Goytacazes, RJ, Brasil, em março de 2011. Anais... Campos dos Goytacazes, RJ, Brasil, 2011.

PAIS, J. M. Lufa-lufa quotidiana. Lisboa: ICS, 2010.

PETLOVE. Disponível em: www.petlove.com.br . Acesso em 28/04/2016.

POLLAN, Michael. O dilema do onívoro: uma história natural de quatro refeições. Rio de Janeiro, Intrínseca, 2007.

RITTO, C; ALVARENGA, B. A casa agora é deles. Veja, Abril, n. 2429, p. 71, 2015.

ROMANELLI, G. "O significado da alimentação na família: uma visão antropológica". Medicina, Ribeirão Preto, 39 (3): 333-339, jul./set., 2006.

SAHD, L. A mente do seu cachorro: tudo que você precisa saber para que seu amigo peludo tenha uma vida saudável e feliz. São Paulo: Abril, 2015.

SANTANA, L.; OLIVEIRA, T. Guarda responsável e dignidade dos animais. 2004. Disponível em: http://www.abolicionismoanimal.org.br/artigos/guardaresponsveledignidadedosanimais.pdf. Acesso em 15/06/2013.

SINGER, Peter. Libertação animal. São Paulo: Martins Fontes, 2010.

VEGPET. Disponível em: www.vegpet.com.br. Acesso em 28/04/2016.

VELDEN, Felipe. Sobre cães e índios: domesticidade, classificação zoológica e relação humano-animal entre os Karitiana. Avá, n.15, p.125-143, 2009.

VERSIGNASSI, A. GARATTONI, B. URBIM, E. Cachorros, por que eles viraram gente? Superinteressante, n.263, p.54-63,Mar. 2009.

WHORTON, J. C. "Historical development of vegetarianism". The American Journal of Clinical Nutrition, 59 (suppl.): 1103-1109, 1994.

Recebido em: 26/10/2016.

Aprovado em: 29/11/2016. 